\title{
Hicri Takvim Etkisi: Borsa İstanbul Gıda-İçecek, Hizmetler ve Ulaştırma Endekslerinde Yer Alan Paylar Üzerine Bir Araştırma
}

\section{Hijri Calendar Effect: A Study on the Stocks of Borsa Istanbul Food-Beverage, Services and Transportation Indices}

\author{
Nasıf ÖZKAN, Dumlupınar Üniversitesi, UBYO, Bankacıllk ve Finans Bölümü, nasif.ozkan@dpu.edu.tr \\ Murat AKBALIK, Marmara Üniversitesi, BSY, Sermaye Piyasası Bölümü, makbalik@ marmara.edu.tr
}

\begin{abstract}
Öz: Bu çalışmada, Aralık 2015 tarihi itibartyla Borsa İstanbul Glda-İçecek, Hizmetler ve Ulaştırma endekslerinde yer alan paylarda Ramazan ayı etkisinin varlı̆̆, payların 4 Mart 2003 - 13 Ekim 2015 (1 Muharrem 1424 - 29 Zilhicce 1436) tarihleri arasindaki getiri verileri kullanılarak arașttrılmaktadır. Literatürde yer alan birçok çalışmadan farklı olarak, Ramazan ayl etkisi bir endeks yerine, Borsa İstanbul'da hesaplanan birkaç endeks (XGIDA, XUHIZ ve XULAS) içinde yer alan bireysel paylar için test edilmektedir. Hicri takvime göre oluşan bu etkiyi analiz etmek içinse, kukla değişkenli regresyon modeli ve Kruskal-Wallis testi kullanılmaktadır. Çalışmanın sonuçları, analize dahil edilen yirmi iki paydan hiç birinde Ramazan ayı etkisinin var olmadı̆̆ını göstermektedir. AKENR ve KIPA paylarının getirileri üzerinde ise, diğer bazı hicri ayların pozitif (Rebiyülahir ve Recep) veya negatif (Rebiyülevvel ve Cemaziyülevvel) etkisi söz konusudur. Bu bulgular, Borsa İstanbul pay piyasasında hicri takvime ilişkin takvimsel etkileri göz önünde bulundurarak anormal getiri elde etmenin zor hale geldiğini kanitlamaktadır.
\end{abstract}

Anahtar Kelimeler: Hicri Ay Etkisi, Ramazan Ayı Etkisi, Takvimsel Anomaliler, Piyasa Etkinliği, Borsa İstanbul Payları

Abstract: In this study, the existence of the Ramadan effect is investigated in the stocks of Borsa Istanbul Food-Beverage, Services and Transportation Indices as of December 2015 using the stocks return data between 4 March 2003 and 13 October 2015 (1 Muharram 1424 - 29 Dhu al-Hijja 1436). Unlike many studies in the literature, the Ramadan effect is being tested for individual stocks in various indices (XGIDA, XUHIZ, and XULAS) instead of an index. In order to analyze this effect, dummy variable regression model and Kruskal-Wallis test are used. The results of the study indicate that the Ramadan effect do not exist any of the twenty-two stocks that are included in the analysis. On the other hand, some other Hijri months have positive (Rabi II and Rajab) or negative effects (Rabi I and Jumada I) on the returns of AKENR and KIPA stocks. These findings demonstrate that it is difficult to obtain abnormal returns in the Borsa Istanbul Equity Market by considering the Hijri calendar effects.

Keywords: Hijri Month Effect, The Ramadan Effect, Calendar Anomalies, Market Efficiency, Borsa Istanbul's Stocks

\section{Giriş}

Günümüzde birçok araştırmacı tarafından geleneksel finans modellerinin finansal piyasaların yapısını tanımlamakta yetersiz olduğu kabul edilmektedir. Bu nedenle yapılan araştırmalar sonrasında psikoloji, sosyoloji ve finans biliminin birleşiminden oluşan davranışsal finans ortaya çıkmış ve piyasalarda oluşan anomalilerin belirlenip açıklanmasında alternatif bir alan olarak gelişme potansiyeli yakalamıştır. Pay piyasalarında görülen anomaliler temel olarak dönemsel (mevsimsel) anomaliler, kesitsel anomaliler ve fiyat anomalileri olmak üzere üç başlık altında toplanabilir (Erdoğan ve Elmas 2010, 2). Finans literatüründe mevsimsel anomaliler (Ocak ayı etkisi, haftanın günü etkisi, tatil etkisi vb. gibi) ile ilgili birçok çalışmaya rastlamak mümkündür. Ancak, hicri (İslami) takvimi ${ }^{1}$ baz alarak pay piyasalarında hicri takvim anomalisini ya da hicri takvim etkisini araştıran sınırlı sayıda çalışma bulunmaktadır.

Müslüman ülkelerde Ramazan ayında oruç tutulması en bilinen dini ibadetlerden biridir. Dünyanın diğer ülke ve dinlerinde nasıl Noel, diwali, yeni yıl vb. gibi kutsal günler, haftalar ve aylar var ise, Ramazan ayı da Müslümanlar için en kutsal aydır ve bu ay on bir ayın sultanı olarak adlandırılmaktadır. Literatürde yer alan çalışmalar (Almudhaf 2012; Białkowski vd. 2012; Iqbal vd. 2013; Mustafa 2011), Ramazan ayında pay getirilerinin, hicri yılın diğer aylarına kıyasla daha yüksek ve daha az oynak olduğunu göstermektedir. Al-Hajieh vd. (2011, 345-347) de Ramazan ayında ortaya çıkan bu durumun, Ramazan ayının yatırımcıların ruh halini ya da duyarlılığını pozitif yönde etkilemesine bağlandığını ileri sürmektedir. Bu bağlamda çalışmada, Borsa İstanbul pay piyasasında Ramazan ayı ve diğer hicri ayların etkisinin varlığı araştırılmaktadır. Araştırmayı yapmak için, 31 Aralık 2015 tarihi itibarıyla BIST Gıda ve İçecek (XGIDA), BIST Hizmetler (XUHIZ) ve BIST Ulaştırma (XULAS) endekslerinde yer alan 22 payın 4 Mart 2003 - 13 Ekim 2015 (1 Muharrem 1424 - 29

\footnotetext{
${ }^{1}$ Hicri takvim, Hz. Muhammed'in Mekke'den Medine'ye hicretiyle başlayan ve Ay'ın Dünya etrafinda dolanımını esas alan bir takvim sistemidir. Bu takvim sisteminde, 1 yıl 354 günden ve 12 aydan oluşmaktadır. Türkiye'de şu anda kullanılan miladi takvim ise, Hz. İsa'nın doğumu ile başlamakta ve Dünya'nın Güneş etrafında dönüş süresi olan 365 gün 6 saatlik zamanı 1 yıl olarak kabul etmektedir. Bu iki takvim sisteminde 1 yılı oluşturan gün sayılarının farklı olmasından dolayı, Müslüman ülkelerde dini gün ve bayramlar, Miladi takvime göre her yıl bir önceki yıla göre yaklaşık 11 gün önce başlamaktadır (Unat 2004, 4).
} 
Zilhicce 1436) tarihleri arasındaki verileri kullanılmaktadır. Hicri yılın aylarına ${ }^{2}$ ilişkin ortalama getirilerin birbirinden farklı olup olmadığını belirlemek içinse, kukla değişkenli regresyon modeli ve parametrik olmayan istatistiksel analiz yöntemlerinden olan Kruskal-Wallis testi uygulanmaktadır. Literatürde yer alan ulusal ve uluslararası çalışmalar (Akbalık 2015; Al-Khazali 2014; Küçüksille ve Özmutaf 2015; Seyyed vd. 2005), Ramazan ayı etkisini araştırmak için veri olarak daha çok borsaların temel endekslerini ya da sektör endekslerini (BIST 100 Endeksi, BIST Hizmetler Endeksi gibi) kullanmaktadır. $\mathrm{Bu}$ bağlamda, hicri takvim etkisinin Borsa İstanbul pay piyasasının gıda-içecek, hizmetler ve ulaştırma endekslerinde işlem gören piyasa değeri yüksek 22 pay için araştırılıyor olması çalışmayı diğerlerinden ayırmaktadır.

Çalışma beş bölümden oluşmaktadır. Giriş bölümünü takip eden ikinci bölümde, hicri takvim etkisini inceleyen literatür çalışmalarına yer verilmektedir. Üçüncü bölümde, çalışmada kullanılan veri seti ve metodoloji açıklanmaktadır. Dördüncü bölümde, analize dahil edilen 22 pay için hicri takvim etkisine dair elde edilen bulgular yorumlanmaktadır. Son bölümde ise, çalışmanın sonuçları özetlenmektedir.

\section{Literatür Taraması}

Husain (1998), 1989-1993 yılları arasında Karaçi pay piyasasında Ramazan ayının ortalama getirisini ve getiri oynaklığını genelleştirilmiş ardışık bağlanımlı koşullu değişen varyans (Generalized Auto Regressive Conditional Heteroscedasticity GARCH) yöntemiyle incelenmiştir. Yazar, incelenen dönemde Ramazan ayı ile diğer hicri ayların ortalama getirilerinin birbirinden farklılık göstermediğini ancak getiri oynaklığının Ramazan ayında önemli ölçüde azaldığını göstermektedir. Seyyed vd. (2005) de Suudi Arabistan pay piyasasında getiri verilerini GARCH yöntemiyle incelemiş̧tir. Yazarlar, Husain (1998)'in bulgularına benzer şekilde Suudi Arabistan pay piyasasında ortalama getirilerin Ramazan ayından etkilenmediğini ancak bu ayda getiri oynaklığında önemli bir düşüş meydana geldiğini ifade etmektedir. Ariss vd. (2011), Körfez Arap Ülkeleri İşbirliği Konseyi ülkeleri pay piyasalarını incelediği çalışmasında Husain (1998) ve Seyyed vd. (2005)'e paralel bulgular sunmaktadır.

Białkowski vd. (2012), 1989-2007 yılları arası dönemde on dört Müslüman ülkede pay getirilerinde Ramazan ayı etkisini araştırmıştır. Yazarlar, Ramazan ayında hicri yılın diğer aylarına göre pay getirilerinin neredeyse dokuz kat daha yüksek ve daha az oynak olduğunu göstermektedir. Al-Hajieh vd. (2011), Orta Doğu'da yer alan sekiz Müslüman ülkenin 1992-2007 yılları arasındaki verilerini kullanarak yaptığı çalışmada, birçok ülkede Ramazan ayı etkisini ortaya koymakta ve Ramazan ayının ilk ve son gününün bir önceki yılın aynı dönemine göre daha yüksek düzeyde anlamlılık gösterdiğini ifade etmektedir. Yazarlar, Ramazan ayında ortaya çıkan bu durumun genel olarak yatırımcıların pozitif ruh haline ya da duyarlılı̆̆ına bağlanabileceğini ileri sürmektedir.

Almudhaf (2012), 1996-2007 yılları arasında 12 ülkede hicri takvimin mevsimsel etkisinin istatistiksel anlamlıllğını incelemiştir. Yazar yatırımcıların, Kuveyt, Ürdün, Pakistan ve Türkiye'de Ramazan ayında pozitif ve istatistiksel olarak anlamlı getiriler sağlandığını vurgulamaktadır. Mustafa (2011) de Aralık 1991-Aralık 2010 tarihleri arası Karaçi pay piyasası günlük verilerini kullanarak hicri ayların etkisini sıradan en küçük kareler (Ordinary Least Square - OLS) tekniği ile araştırmıştır. Yazar, incelenen dönem için Almudhaf (2012)'nin bulgularına paralel olarak Karaçi pay piyasasında Ramazan ayı etkisinin varlığını ortaya koymaktadır. Karaçi pay piyasasında miladi ve hicri takvime dayalı anomalileri, 1992-2011 yılları arası dönem için OLS tekniğini kullanarak araştırmış Iqbal vd. (2013) ise, bu piyasada haftanın günü, yılın ayı, ay sonu, ay ortası ve hicri ay etkisinin varlığına dair bulgular sunmaktadır. Ayrıca yazarlar, piyasada istatistiksel olarak anlamlı Ramazan ayı etkisinin varlığını da ortaya koymaktadır. Küçüksille ve Özmutaf (2015) ise, Almudhaf (2012)'nin bulgularının aksine 1988-2014 döneminde Türkiye pay piyasasında Ramazan ayı etkisinin olmadığını ileri sürmekte ve incelen dönemde Recep ayının en yüksek, Rebiyülahir ayının en düşük, Ramazan ayının ise en yüksek ortalama getiriye sahip dördüncü ay olduğunu belirtmektedir. Borsa İstanbul endekslerinde Ramazan ayı etkisinin varlığını araştıran Akbalık (2015) de sadece BIST Hizmetler ve BIST Ulaştırma endekslerinde Ramazan ayı etkisinin varlığını ortay koymakta ve bu etkinin son yıllarda azalmaya başladığını ileri sürmektedir.

Białkowski vd. (2013), 2000-2011 yılları arasında Türk paylarına yatırım yapan yatırım fonu yöneticilerinin Ramazan ayı etkisinden yararlanıp yararlanmadıklarını incelemiştir. Yazarlar, yurtiçi kurumsal, hibrid ve yabancı pay fonlarının Ramazan ayında hicri yılın diğer aylarına göre daha yüksek performans sergilediklerini göstermektedir. Diğer taraftan yazarlar, yurtiçi endeks fonlarının Ramazan ayında artan para girişi nedeniyle Ramazan ayından ters yönde etkilendiklerini ve yüksek anormal getiri sağlayamadıklarını ifade etmektedir. Küresel çaplı ve daha çok paylara yatırım yapan 52 İslami yatırım fonunun performansları üzerinde Ramazan ayı etkisinin varlığını araştırmış Alrashidi vd. (2014) ise, bu ayda İslami yatırım fonlarının getirilerinde önemli bir değişiklik olmamasına rağmen oynaklıkta ciddi bir düşüşün yaşandığını vurgulamaktadır.

Oğuzsoy ve Güven (2004), dini bayramların (Ramazan ve Kurban) 1988-1999 yılları arasında İstanbul Menkul Kıymetler Borsası'nda (şimdiki adıyla Borsa İstanbul) işlem gören paylar üzerindeki etkisinin varlığını araştırmıştır. Yazarlar, İMKB 100 (şimdiki adıyla BIST 100) endeksinin dini tatil günlerine iki gün kala daha yüksek getiri sağladığını ve İMKB 30 (şimdiki

\footnotetext{
${ }^{2}$ Bu aylar; Muharrem, Safer, Rebiyülevvel, Rebiyülahir, Cemaziyülevvel, Cemaziyülahır, Recep, Şaban, Ramazan, Şevval, Zilkade ve Zilhicce olarak siralanabilir.
} 
adıyla BIST 30) endeksi paylarının 17'sinin ortalama getirilerinin dini bayramlara iki gün kala diğer günlere göre yedi kat daha fazla ortalama getiri sağladığını göstermektedir. Ayrıca yazarlar, İMKB 30 endeksinde yer alan payların 21'i için de günlük getiri performansının kutsal günlerde $\% 2$ daha fazla olduğunu ifade etmektedir.

\section{Veri Ve Metodoloji}

Bu çalışmada, 31 Aralık 2015 tarihi itibarıyla BIST Gıda ve İçecek (XGIDA), BIST Hizmetler (XUHIZ) ve BIST Ulaştırma (XULAS) endekslerinde yer alan payların 4 Mart 2003 - 13 Ekim 2015 (1 Muharrem 1424 - 29 Zilhicce 1436) dönemine ait günlük kapanış fiyatları kullanılmaktadır. Veriler, Bloomberg veri tabanından elde edilmiştir. Payların analize dahil edilebilmesi için yukarıda sayılan endekslerin yanında Borsa İstanbul'un temel endeksi olan BIST 100 endeksi (XU100) içinde de yer alması gerekmektedir. Bu nedenle XGIDA, XUHIZ ve XULAS endekslerinde yer alan toplam 76 paydan sadece 22'si çalışma kapsamında incelenmektedir ${ }^{3}$. Çalışmada sadece bu endeksler içinde yer alan paylara odaklanılmasının ilk nedeni, Akbalık (2015)'in XUHIZ ve XULAS endekslerinde Ramazan ayı etkisinin varlığını gösteren bulgular ortaya koymasıdır. İkinci olarak ise, Ramazan ayında yatırımcıların bu endekslerde yer alan paylara olan ilgisinin yüksek olacağı beklentisidir. Tablo 1'de analiz kapsamında incelenecek payların dahil oldukları endeksler, analiz edilen gün sayısı ve hicri ya da miladi takvime göre analize başlama tarihleri sunulmaktadır'. Tablo 1'den görüldüğü gibi örnekleme dahil edilen şirketlerin 12'si (\%55) XUHIZ, 6'sı XULAS (\%27) ve 4'ü de XGIDA (\%18) endeksi içinde yer almaktadır. XULAS endeksi payları aynı zamanda XUHIZ endeksine de dahildir. Bazı paylar, 2003 yılından sonra Borsa İstanbul'da işlem görmeye başlamıştır. Bu nedenle bu paylar için analize başlangıç tarihi 4 Mart 2003'ten (1 Muharrem 1424) farklıdır. Örneğin AKSEN için analize başlama tarihi bu payın borsada ilk işlem görmeye başladığı tarih olan 24 Mayıs 2010'dur (10 Cemaziyülahır 1431). Tablo 1'de gösterildiği gibi, on bir pay için analize başlama tarihi 4 Mart 2003'tür (1 Muharrem 1424).

Tablo 1. Paylara ve Analize İlişkin Bilgiler

\begin{tabular}{|c|c|c|c|c|}
\hline \multirow{2}{*}{ Pay Kodu } & \multirow{2}{*}{ Endeks } & \multirow{2}{*}{ Analiz Edilen Gün Sayısı } & \multicolumn{2}{|c|}{ Analize Başlama Tarihi } \\
\hline & & & Miladi Takvim & Hicri Takvim \\
\hline AEFES & $X G I D A$ & 3170 & 04 Mart 2003 & 1 Muharrem 1424 \\
\hline AKENR & XUHIZ & 3170 & 04 Mart 2003 & 1 Muharrem 1424 \\
\hline AKSEN & XUHIZ & 1356 & 24 Mayıs 2010 & 10 Cemaziyülahır 1431 \\
\hline BIMAS & XUHIZ & 2577 & 15 Теттив 2005 & 8 Cemaziyülahır 1426 \\
\hline BIZIM & XUHIZ & 1181 & 03 Şubat2011 & 30 Safer 1432 \\
\hline CCOLA & $X G I D A$ & 2369 & 15 Mayls 2006 & 17 Rebiyülahir 1427 \\
\hline CLEBI & XULAS, XUHIZ & 3170 & 04 Mart 2003 & 1 Muharrem 1424 \\
\hline CRFSA & XUHIZ & 1453 & 05 Ocak 2010 & 20 Muharrem 1431 \\
\hline$D O A S$ & XUHIZ & 2489 & 17 Haziran 2004 & 29 Rebiyülahir 1425 \\
\hline DOCO & XULAS, XUHIZ & 1226 & 02 Aralık 2010 & 26 Zilhicce 1431 \\
\hline KIPA & XUHIZ & 3170 & 04 Mart 2003 & 1 Muharrem 1424 \\
\hline MGROS & XUHIZ & 3170 & 04 Mart 2003 & 1 Muharrem 1424 \\
\hline NTTUR & XUHIZ & 3170 & 04 Mart 2003 & 1 Muharrem 1424 \\
\hline$O D A S$ & XUHIZ & 600 & 22 Mayls 2013 & 12 Rесер 1434 \\
\hline PGSUS & XULAS, XUHIZ & 616 & 29 Nisan 2013 & 19 Cemaziyülahır 1434 \\
\hline TATGD & $X G I D A$ & 3170 & 04 Mart 2003 & 1 Muharrem 1424 \\
\hline TCELL & XULAS, XUHIZ & 3170 & 04 Mart 2003 & 1 Muharrem 1424 \\
\hline THYAO & XULAS, XUHIZ & 3170 & 04 Mart 2003 & 1 Muharrem 1424 \\
\hline TKNSA & XUHIZ & 855 & 17 Mayıs 2012 & 26 Cemaziyülahır 1433 \\
\hline TTKOM & XULAS, XUHIZ & 1862 & 15 Mayls 2008 & 10 Cemaziyülevvel 1429 \\
\hline ULKER & $X G I D A$ & 3170 & 04 Mart 2003 & 1 Muharrem 1424 \\
\hline
\end{tabular}

\footnotetext{
${ }^{3}$ BIST Hizmetler endeksinde, futbol ile ilgili faaliyetler sürdüren paylar (BJKAS, FENER ve GSRAY) analiz kapsamı dışındadır. ${ }^{4}$ Hicri aylara ilişkin günler, aşağıda Diyanet İşleri Başkanlığı tarafından sağlanan web sitesinden dönüştürülmüştür. http://www.staff.science.uu.nl/ gent0113/islam/diyanetcalendar_converter.htm
} 
XGIDA, BIST Gıda ve İçecek; XUHIZ, BIST Hizmetler ve XULAS, BIST Ulaştırma endekslerini ifade etmektedir. XULAS endeksinde yer alan paylar aynı zamanda XUHIZ endeksinde de yer almaktadır.

Paylara ilişkin günlük getiriler aşağıdaki denklem yardımıyla hesaplanmaktadır:

$$
\mathrm{R}_{\mathrm{it}}=\ln \left(\frac{\mathrm{P}_{\mathrm{it}}}{\mathrm{P}_{\mathrm{it}-1}}\right)
$$

Denklem (1)'deki $R_{i t}$; i payının t günündeki logaritmik getirisini, $P_{i t}$; i payının t günündeki kapanıs fiyatını, $P_{i t-1}$ ise; i payının t-1 günündeki kapanış fiyatını temsil etmektedir. Veri setinde yer alan uç değerlerin sonuçlar üzerinde yaratacağı olumsuz etkileri ortadan kaldırmak için getiriler, doğal logaritmaları (ln) alınarak hesaplanmaktadır (Ergül vd. 2009, 138; Ergül vd. 2008, 606; Tunçel 2007, 259).

Çalışmada hicri takvim etkisini test etmek için kukla değiş̧kenli regresyon modeli tekniği kullanılmaktadır. Bu modelde kukla değiş̧en belirli bir hicri ayı temsil etmekte ve bu aydaki işlem günleri 1 değerini; hicri yılın diğer aylarındaki işlem günleri ise 0 değerini almaktadır ${ }^{5}$. Çalışmada hicri takvim etkisini test etmek için aşağıdaki regresyon denklemi tahmin edilmektedir:

$$
R_{\text {it }}=\beta_{1 \mathrm{i}}+\beta_{2 \mathrm{i}} \mathrm{D}_{2 \mathrm{i}}+\beta_{3 \mathrm{i}} \mathrm{D}_{3 \mathrm{i}}+\cdots+\beta_{9 \mathrm{i}} \mathrm{D}_{9 \mathrm{i}}+\beta_{10 \mathrm{i}} \mathrm{D}_{10 \mathrm{i}}+\beta_{11 \mathrm{i}} \mathrm{D}_{11 \mathrm{i}}+\beta_{12 \mathrm{i}} \mathrm{D}_{12 \mathrm{i}}+\varepsilon_{\mathrm{it}}
$$

Denklem (2)'de $\mathrm{R}_{\mathrm{it}}$, i payının t günündeki getirisini; $\mathrm{D}_{2 \mathrm{i}}, \ldots \mathrm{D}_{12 \mathrm{i}}$, i payının her bir hicri aydaki kukla değişkenlerini temsil etmektedir. Herhangi bir i payı için $\mathrm{D}_{2 \mathrm{i}}$, eğer Safer ayı ise 1 , değilse 0; $\mathrm{D}_{3 \mathrm{i}}$, eğer Rebiyülevvel ayı ise 1 , değilse 0 ; $\mathrm{D}_{4 \mathrm{i}}$, eğer Rebiyülahir ayı ise 1 , değilse $0 ; \ldots D_{12 i}$, eğer Zilhicce ayı ise 1 , değilse 0 değerini almaktadır. $\beta_{1 i}$ regresyon modelinin sabit terimini, diğer $\beta$ 'lar regresyon modelinin eğim katsayılarını, $\varepsilon_{\text {it }}$ ise hata terimini ifade etmektedir. Herhangi bir i payı için, örneğin, $\beta_{9 \mathrm{i}}$ katsayısının istatistiksel olarak anlamlı bir şekilde pozitif olması, o payda Ramazan ayı etkisinin varlığını ortaya koymaktadır.

Kukla değişkenli regresyon modeli, pay getirilerinin normal dağılım gösterdiğini varsayarak uygulanmaktadır. Ancak, pay getirilerine ilişkin veriler normal dağılım göstermeyebilir. Bu nedenle getiri verilerinin normal dağılıma uyup uymadığı Jarque-Bera ve Kolmogorov-Smirnov (K-S) testleriyle araştırılmaktadır. Bu testlerin sonuçlarına göre, pay getirilerinin normal dağılım özelliklerine uymadıkları tespit edilmiştir (Tablo 2 ve 4). Bu nedenle de kukla değişkenli regresyon modelinin sonuçlarını doğrulamak için parametrik olmayan istatistiksel analiz yöntemlerinden olan Kruskal-Wallis testine (KW) başvurularak hicri yılın aylarına ilişkin ortalama getirilerin birbirinden farklı olup olmadığı belirlenmektedir. Kruskal-Wallis testi, tek yönlü varyans analizinin (one-way ANOVA) parametrik olmayan alternatifi olarak bilinmektedir. Bu test, sürekli değiş̧kenlere sahip üç ya da daha fazla grup için karşılaştırma yapmayı sağlamaktadır (Kalaycı 2010, 106). Kruskal-Wallis testinde, KW değeri (ki-kare istatistiği) aşağıdaki formülle hesaplanmaktadır (Hui 2005, 279; Kumar ve Pathak 2016, 146; Lim ve Chia 2010, 2):

$$
K W=\frac{12}{n(n+1)} \sum_{j=1}^{k} \frac{R_{j}^{2}}{n_{j}}-3(n+1)
$$

Denklem (3)'te $R_{j}$, j grubundaki sıralama sayılarının toplamını; $n$, getirilerin toplam gözlem sayısını; $n_{j}, j$ grubundaki toplam gözlem sayısını ve k, grup sayısını göstermektedir.

Çalışmada, hicri takvim etkisinin varlığını Kruskal-Wallis testini kullanarak test etmek için oluşturulan hipotezler aşağıdaki gibidir.

$\mathrm{H}_{0}$ : Payların hicri aylarda sağladığı ortalama getiriler arasında farklılık yoktur.

$\mathrm{H}_{1}$ : Payların hicri aylarda sağladığı ortalama getiriler arasında farklılık vardır.

Kruskal-Wallis testi sonucunda, sıfir hipotezinin $\left(\mathrm{H}_{0}\right)$ reddedilmesi bir başka ifadeyle alternatif hipotezin $\left(\mathrm{H}_{1}\right)$ reddedilememesi durumunda hicri ay etkisinin varlı̆̆ kabul edilmektedir. Böyle bir sonuç, payların hicri aylarda sağladığı ortalama getiriler arasında istatistiksel olarak anlamlı bir farklılık olduğunu işaret etmektedir.

\section{Ampirik Bulgular}

BIST Gıda-İçecek, Hizmetler ve Ulaştırma endekslerinde yer alan yirmi iki payın getirilerine ilişkin tanımlayıcı istatistikler Tablo 2'de sunulmaktadır. Tablo 2'de yer alan sonuçlara göre, analiz edilen tüm aylar için sadece dört pay (BIMAS, DOCO, THYAO ve ULKER) istatistiksel olarak anlamlı pozitif getiri sağlamaktadır. Bunların dışında kalan paylara ait getiriler ise, istatistiksel olarak anlamsız, bir başka ifadeyle sıfırdan farksızdır. En yüksek getiri \%21,73 ile BIMAS payında, en düşük getiri ise \%-25,14 ile CLEBI payında gözlemlenmektedir. Diğer taraftan en yüksek değişkenlik NTTUR payına, en düşük değişkenlik ise DOCO payına aittir. Jarque-Bera istatistiği sonuçlarına göre ise, getirilerin normal dağıldığı varsayımı tüm paylar için \%1 istatistiksel anlamlılık düzeyinde reddedilmektedir. Bunun anlamı paylara iliş̧in hiçbir getiri serisinin normal dağılmadığıdır.

\footnotetext{
${ }^{5}$ Hicri takvimde 1 yıl 354 günden ve 12 aydan oluşmaktadır. Bu aylar; Muharrem, Safer, Rebiyülevvel, Rebiyülahir, Cemaziyülevvel, Cemaziyülahır, Recep, Şaban, Ramazan, Şevval, Zilkade ve Zilhicce olarak sıralanabilir. Ramazan ayı, hicri takvimin dokuzuncu ayıdır.
} 
Payların, hicri takvimin aylarına (Muharrem, Safer, Rebiyülevvel, Rebiyülahir, Cemaziyülevvel, Cemaziyülahır, Recep, Şaban, Ramazan, Şevval, Zilkade ve Zilhicce) ilişkin ortalama getiri ve standart sapma değerleri Tablo 3 Panel A ve Panel B'de sunulmaktadır. Hicri takvimin aylarına ilişkin ortalama getiriler tek tek incelendiğinde, Muharrem ve Safer aylarında tüm payların sağladığı getirilerin istatistiksel olarak anlamsız olduğu görülmektedir. Diğer bazı aylarda ise, paylar pozitif ya da negatif getiriler sağlamaktadır. Literatürde yer alan bazı çalışmalarının aksine (Białkowski vd., 2012), tüm payların Ramazan ayında diğer hicri aylara göre pozitif ve daha yüksek getiri sağladığı ortaya koyulamamaktadır. Paylara ilişkin hicri ay ortalama getirileri genel olarak değerlendirildiğinde, çoğunun sıfira yakın olduğu görülmektedir. 
Özkan, N., Akbalık, M. / Journal of Yasar University, 2018, 13/49, 9-21

Tablo 2. Paylara İlişkin Tanımlayıcı İstatistikleri

\begin{tabular}{|c|c|c|c|c|c|c|c|c|}
\hline & Ortalama & Std. Sapma & Maksimum & Minimum & Çarpıklık & Basıklık & Jarque-Bera & $p$-değgeri ${ }^{a}$ \\
\hline AEFES & 0,0007 & 0,0241 & 0,1302 & $-0,1498$ & $-0,1335$ & 6,3797 & $1.518,16$ & 0,0000 \\
\hline AKENR & 0,0001 & 0,0249 & 0,1566 & $-0,1842$ & 0,0366 & 9,0837 & $4.889,26$ & 0,0000 \\
\hline AKSEN & $-0,0004$ & 0,0206 & 0,1054 & $-0,1579$ & $-0,5601$ & 8,5132 & $1.788,26$ & 0,0000 \\
\hline$B I M A S$ & $0,0013^{* * *}$ & 0,0238 & 0,2173 & $-0,1651$ & 0,3395 & 12,5293 & $9.799,98$ & 0,0000 \\
\hline BIZIM & $-0,0005$ & 0,0186 & 0,0789 & $-0,1455$ & $-0,9463$ & 11,0654 & $3.377,27$ & 0,0000 \\
\hline CCOLA & 0,0007 & 0,0243 & 0,1666 & $-0,1423$ & 0,2147 & 6,5242 & $1.244,17$ & 0,0000 \\
\hline CLEBI & 0,0008 & 0,0288 & 0,1911 & $-0,2514$ & 0,3832 & 10,2014 & $6.927,46$ & 0,0000 \\
\hline CRFSA & 0,0006 & 0,0223 & 0,1602 & $-0,1491$ & 0,8412 & 12,3982 & $5.518,81$ & 0,0000 \\
\hline$D O A S$ & 0,0004 & 0,0279 & 0,1278 & $-0,1726$ & $-0,4414$ & 6,7539 & $1.765,36$ & 0,0000 \\
\hline DOCO & $0,0015^{* * *}$ & 0,0173 & 0,1301 & $-0,1373$ & 0,4434 & 12,3697 & $4.524,83$ & 0,0000 \\
\hline KIPA & 0,0003 & 0,0236 & 0,1868 & $-0,2081$ & 0,7352 & 14,3513 & $17.304,65$ & 0,0000 \\
\hline MGROS & 0,0006 & 0,0240 & 0,1900 & $-0,2049$ & 0,3254 & 11,9680 & $10.678,73$ & 0,0000 \\
\hline NTTUR & 0,0007 & 0,0292 & 0,1999 & $-0,1515$ & 0,7133 & 9,4986 & $5.846,95$ & 0,0000 \\
\hline$O D A S$ & 0,0006 & 0,0282 & 0,1652 & $-0,1365$ & 0,3548 & 8,6237 & 803,24 & 0,0000 \\
\hline PGSUS & 0,0001 & 0,0265 & 0,0932 & $-0,1398$ & $-0,1013$ & 4,9827 & 101,95 & 0,0000 \\
\hline TATGD & 0,0006 & 0,0237 & 0,1486 & $-0,1343$ & 0,1604 & 7,2415 & $2.389,86$ & 0,0000 \\
\hline TCELL & 0,0005 & 0,0230 & 0,1189 & $-0,1493$ & $-0,0649$ & 6,7953 & $1.903,59$ & 0,0000 \\
\hline ТНYАO & $0,0008^{*}$ & 0,0248 & 0,1351 & $-0,2041$ & $-0,1341$ & 7,7398 & $2.976,83$ & 0,0000 \\
\hline TKNSA & $-0,0002$ & 0,0213 & 0,1082 & $-0,2111$ & $-1,0884$ & 18,3596 & $8.573,34$ & 0,0000 \\
\hline ТТКОМ & 0,0002 & 0,0211 & 0,1082 & $-0,2111$ & $-0,6746$ & 12,5407 & $7.203,20$ & 0,0000 \\
\hline ULKER & $0,0011^{* *}$ & 0,0256 & 0,1788 & $-0,1937$ & 0,6458 & 11,2516 & $9.213,76$ & 0,0000 \\
\hline ZOREN & 0,0001 & 0,0282 & 0,1654 & $-0,2200$ & 0,5093 & 10,5493 & $7.664,74$ & 0,0000 \\
\hline
\end{tabular}


Özkan, N., Akbalık, M. / Journal of Yasar University, 2018, 13/49, 9-21

Tablo 3. Payların Hicri Takvimin Aylarına İlişkin Tanımlayıcı İstatistikleri

\begin{tabular}{|c|c|c|c|c|c|c|c|c|c|c|c|c|}
\hline \multicolumn{13}{|c|}{ Panel A: Hicri Aylara İlişkin Ortalama Getiriler } \\
\hline & Muharrem & Safer & Rebiyülevvel & Rebiyülahir & Cemaziyülevvel & Cemaziyülahır & Recep & Şaban & Ramazan & Şevval & Zilkade & Zilhicce \\
\hline AEFES & 0,0004 & $-0,0002$ & 0,0000 & $-0,0004$ & $0,0029^{* *}$ & 0,0001 & $0,0031^{* *}$ & 0,0006 & 0,0004 & 0,0011 & $-0,0004$ & 0,0008 \\
\hline$A K E N R$ & 0,0011 & 0,0009 & $-0,0027^{* *}$ & 0,0021 & $-0,0028^{* *}$ & $0,0030^{* *}$ & 0,0006 & $-0,0008$ & 0,0015 & $-0,0009$ & $-0,0001$ & $-0,0016$ \\
\hline AKSEN & 0,0022 & 0,0016 & $-0,0007$ & 0,0017 & $-0,0002$ & $-0,0002$ & $-0,0033$ & $-0,0019$ & $-0,0012$ & $-0,0015$ & 0,0020 & $-0,0024$ \\
\hline BIMAS & 0,0019 & 0,0007 & 0,0004 & $0,0029^{*}$ & 0,0006 & 0,0016 & 0,0026 & 0,0021 & $-0,0002$ & $-0,0007$ & 0,0015 & 0,0018 \\
\hline BIZIM & 0,0000 & 0,0028 & $-0,0018$ & 0,0015 & 0,0002 & $-0,0008$ & $-0,0010$ & $-0,0022$ & $-0,0025$ & $-0,0023$ & 0,0015 & $-0,0006$ \\
\hline CCOLA & 0,0002 & $-0,0004$ & $-0,0005$ & $-0,0002$ & 0,0019 & 0,0007 & $0,0025^{*}$ & 0,0006 & 0,0002 & $-0,0020$ & 0,0024 & 0,0021 \\
\hline CLEBI & 0,0029 & $-0,0016$ & $-0,0004$ & $0,0030^{*}$ & $-0,0017$ & $-0,0011$ & 0,0013 & $0,0036^{*}$ & 0,0011 & $-0,0040^{* *}$ & $0,0034^{*}$ & 0,0025 \\
\hline CRFSA & 0,0001 & $-0,0016$ & 0,0025 & $0,0062^{* *}$ & 0,0002 & $-0,0007$ & $0,0047^{* *}$ & $-0,0017$ & $-0,0021$ & 0,0002 & $-0,0003$ & $-0,0005$ \\
\hline$D O A S$ & 0,0021 & $-0,0027$ & 0,0026 & 0,0014 & $-0,0030^{*}$ & 0,0007 & $0,0041^{* *}$ & $-0,0006$ & 0,0023 & $-0,0027$ & $-0,0009$ & 0,0015 \\
\hline DOCO & 0,0026 & 0,0017 & 0,0018 & 0,0012 & 0,0019 & $-0,0002$ & 0,0024 & 0,0010 & 0,0009 & 0,0010 & $-0,0003$ & 0,0035 \\
\hline$K I P A$ & $-0,0007$ & $-0,0004$ & 0,0001 & $0,0042^{* * *}$ & 0,0017 & $-0,0012$ & $0,0034^{* *}$ & 0,0017 & $-0,0011$ & $-0,0026$ & $-0,0016$ & 0,0000 \\
\hline MGROS & 0,0017 & $-0,0002$ & 0,0002 & $0,0030^{*}$ & $-0,0006$ & 0,0005 & $0,0027^{*}$ & 0,0028 & $-0,0015$ & $-0,0008$ & $-0,0001$ & $-0,0010$ \\
\hline NTTUR & $-0,0002$ & 0,0035 & $-0,0002$ & 0,0021 & $-0,0014$ & $-0,0004$ & 0,0007 & $-0,0002$ & 0,0007 & 0,0018 & 0,0012 & 0,0011 \\
\hline$O D A S$ & 0,0006 & $-0,0002$ & 0,0040 & 0,0068 & 0,0026 & 0,0043 & $-0,0015$ & $-0,0029$ & 0,0003 & $-0,0074^{* * *}$ & 0,0008 & $0,0045^{*}$ \\
\hline PGSUS & 0,0043 & 0,0007 & $-0,0095^{* *}$ & 0,0000 & $-0,0038$ & $-0,0002$ & 0,0043 & 0,0002 & 0,0030 & $-0,0051$ & 0,0011 & 0,0035 \\
\hline$T A T G D$ & $-0,0002$ & 0,0000 & $-0,0006$ & 0,0020 & $-0,0002$ & $0,0030^{* *}$ & 0,0015 & 0,0009 & $-0,0014$ & 0,0006 & 0,0019 & $-0,0010$ \\
\hline TCELL & 0,0010 & $-0,0005$ & $-0,0014$ & $-0,0003$ & $-0,0003$ & $-0,0018$ & 0,0017 & $0,0027^{* *}$ & 0,0021 & 0,0016 & 0,0012 & 0,0005 \\
\hline THYAO & 0,0024 & $-0,0016$ & 0,0008 & 0,0009 & $-0,0015$ & 0,0001 & $0,0026^{*}$ & 0,0022 & 0,0016 & $-0,0019$ & $0,0028^{*}$ & 0,0007 \\
\hline TKNSA & $-0,0018$ & 0,0031 & 0,0005 & $-0,0017$ & 0,0007 & 0,0004 & 0,0013 & $-0,0020$ & $0,0034^{* *}$ & $-0,0069^{* *}$ & $-0,0011$ & 0,0022 \\
\hline TTKOM & 0,0015 & 0,0010 & 0,0002 & 0,0017 & 0,0006 & $-0,0017$ & 0,0025 & $-0,0016$ & 0,0018 & $-0,0040^{*}$ & $-0,0005$ & 0,0009 \\
\hline ULKER & 0,0032 & $-0,0005$ & $-0,0015$ & 0,0011 & 0,0012 & 0,0025 & $0,0032^{*}$ & 0,0019 & $-0,0008$ & $-0,0020$ & 0,0014 & $0,0031^{\text {** }}$ \\
\hline ZOREN & 0,0010 & $-0,0017$ & $-0,0001$ & 0,0019 & 0,0006 & 0,0003 & 0,0005 & $-0,0007$ & 0,0002 & $-0,0025$ & 0,0010 & $-0,0002$ \\
\hline
\end{tabular}


Özkan, N., Akbalık, M. / Journal of Yasar University, 2018, 13/49, 9-21

Tablo 3 (devam ediyor)

\begin{tabular}{|c|c|c|c|c|c|c|c|c|c|c|c|c|}
\hline \multicolumn{13}{|c|}{ Panel B: Hicri Ayların Ortalama Getirilerine İlişkin Standart Sapma Değerleri } \\
\hline & Muharrem & Safer & Rebiyülevvel & Rebiyülahir & Cemaziyülevvel & Cemaziyülahır & Recep & Şaban & Ramazan & Şevval & Zilkade & Zilhicce \\
\hline AEFES & 0,0242 & 0,0240 & 0,0194 & 0,0243 & 0,0229 & 0,0221 & 0,0253 & 0,0297 & 0,0241 & 0,0264 & 0,0231 & 0,0222 \\
\hline$A K E N R$ & 0,0289 & 0,0247 & 0,0219 & 0,0215 & 0,0221 & 0,0244 & 0,0251 & 0,0263 & 0,0232 & 0,0269 & 0,0301 & 0,0221 \\
\hline AKSEN & 0,0190 & 0,0237 & 0,0185 & 0,0145 & 0,0181 & 0,0144 & 0,0248 & 0,0235 & 0,0247 & 0,0217 & 0,0210 & 0,0178 \\
\hline BIMAS & 0,0190 & 0,0250 & 0,0209 & 0,0224 & 0,0208 & 0,0230 & 0,0257 & 0,0203 & 0,0261 & 0,0267 & 0,0318 & 0,0201 \\
\hline BIZIM & 0,0166 & 0,0193 & 0,0166 & 0,0176 & 0,0164 & 0,0187 & 0,0214 & 0,0231 & 0,0209 & 0,0192 & 0,0168 & 0,0147 \\
\hline CCOLA & 0,0221 & 0,0244 & 0,0231 & 0,0205 & 0,0220 & 0,0239 & 0,0207 & 0,0233 & 0,0277 & 0,0307 & 0,0278 & 0,0231 \\
\hline CLEBI & 0,0286 & 0,0283 & 0,0277 & 0,0283 & 0,0242 & 0,0295 & 0,0280 & 0,0314 & 0,0289 & 0,0294 & 0,0330 & 0,0269 \\
\hline CRFSA & 0,0187 & 0,0158 & 0,0206 & 0,0308 & 0,0279 & 0,0259 & 0,0236 & 0,0234 & 0,0197 & 0,0245 & 0,0145 & 0,0135 \\
\hline$D O A S$ & 0,0275 & 0,0286 & 0,0259 & 0,0300 & 0,0267 & 0,0278 & 0,0280 & 0,0246 & 0,0261 & 0,0331 & 0,0302 & 0,0250 \\
\hline$D O C O$ & 0,0167 & 0,0145 & 0,0172 & 0,0140 & 0,0164 & 0,0142 & 0,0190 & 0,0162 & 0,0248 & 0,0152 & 0,0133 & 0,0224 \\
\hline$K I P A$ & 0,0296 & 0,0242 & 0,0179 & 0,0248 & 0,0239 & 0,0210 & 0,0246 & 0,0268 & 0,0195 & 0,0256 & 0,0242 & 0,0163 \\
\hline MGROS & 0,0243 & 0,0228 & 0,0207 & 0,0268 & 0,0257 & 0,0219 & 0,0238 & 0,0309 & 0,0196 & 0,0267 & 0,0218 & 0,0210 \\
\hline NTTUR & 0,0263 & 0,0407 & 0,0280 & 0,0308 & 0,0316 & 0,0252 & 0,0231 & 0,0287 & 0,0321 & 0,0293 & 0,0257 & 0,0238 \\
\hline$O D A S$ & 0,0224 & 0,0325 & 0,0233 & 0,0330 & 0,0493 & 0,0278 & 0,0401 & 0,0215 & 0,0172 & 0,0213 & 0,0237 & 0,0192 \\
\hline PGSUS & 0,0269 & 0,0300 & 0,0310 & 0,0281 & 0,0250 & 0,0206 & 0,0338 & 0,0240 & 0,0223 & 0,0301 & 0,0244 & 0,0196 \\
\hline$T A T G D$ & 0,0245 & 0,0263 & 0,0208 & 0,0239 & 0,0232 & 0,0215 & 0,0199 & 0,0261 & 0,0257 & 0,0282 & 0,0231 & 0,0189 \\
\hline TCELL & 0,0231 & 0,0230 & 0,0216 & 0,0224 & 0,0209 & 0,0227 & 0,0215 & 0,0223 & 0,0253 & 0,0254 & 0,0241 & 0,0237 \\
\hline THYAO & 0,0257 & 0,0253 & 0,0267 & 0,0233 & 0,0236 & 0,0206 & 0,0248 & 0,0240 & 0,0233 & 0,0311 & 0,0256 & 0,0219 \\
\hline TKNSA & 0,0145 & 0,0215 & 0,0199 & 0,0139 & 0,0241 & 0,0213 & 0,0302 & 0,0267 & 0,0152 & 0,0251 & 0,0140 & 0,0196 \\
\hline TTKOM & 0,0179 & 0,0199 & 0,0181 & 0,0152 & 0,0197 & 0,0247 & 0,0244 & 0,0237 & 0,0205 & 0,0256 & 0,0193 & 0,0207 \\
\hline ULKER & 0,0319 & 0,0258 & 0,0241 & 0,0218 & 0,0278 & 0,0250 & 0,0317 & 0,0233 & 0,0197 & 0,0250 & 0,0257 & 0,0219 \\
\hline ZOREN & 0,0280 & 0,0270 & 0,0263 & 0,0279 & 0,0256 & 0,0262 & 0,0252 & 0,0285 & 0,0281 & 0,0303 & 0,0305 & 0,0350 \\
\hline
\end{tabular}

${ }^{* * *},{ }^{* *} v e{ }^{*}$ hicri ay ortalama getirilerinin t-testine göre istatistik
analize başlangıç tarihleri Tablo I'de açılandığı gibidir. 
Tablo 4, payların getiri serilerine ilişkin Kolmogorov-Smirnov normallik testi (K-S) ve Augmented Dickey Fuller birim kök testi (ADF) sonuçlarını göstermektedir. Tüm getiri serileri için normal dağılımın varlığını iddia eden sıfır hipotezi \%1 anlamlılık düzeyinde reddedilmektedir. Bu sonuç, Tablo 2'de yer alan Jarque- Bera normallik testine benzer şekilde paylara ilişkin zaman serilerinin hiçbirinin normal dağılıma uymadığını işaret etmektedir. ADF testinde ise, getiri serilerinin birim kök içerdiğini ya da serilerin durağan olmadığını iddia eden sıfır hipotezi \%1 anlamlılık düzeyinde tüm getiri serileri için reddedilmektedir. Bu sonuçlar, paylara ilişkin getiri serilerinin birim kök içermediklerini bir başka ifadeyle serilerin düzeyde durağan oldukları anlamına gelmektedir.

Tablo 4. Kolmogorov-Smirnov Normallik Testi ve Augmented Dickey Fuller Birim Kök Testi Sonuçları

\begin{tabular}{|c|c|c|}
\hline & K-S Testi (p-değeri) & ADF Testi (p-değeri) \\
\hline AEFES & $0,060^{* * *}(0,0000)$ & $-42,8794^{* * * *}(0,0000)$ \\
\hline AKENR & $0,114^{* * *}(0,0000)$ & $-53,7831^{* * *}(0,0001)$ \\
\hline AKSEN & $0,078^{* * *}(0,0000)$ & $-37,3609^{* * *}(0,0000)$ \\
\hline BIMAS & $0,060^{* * *}(0,0000)$ & $-53,3747^{* * * *}(0,0001)$ \\
\hline BIZIM & $0,080^{* * *}(0,0000)$ & $-32,5830^{* * *}(0,0000)$ \\
\hline CCOLA & $0,058^{* * *}(0,0000)$ & $-50,0239^{* * * *}(0,0001)$ \\
\hline CLEBI & $0,082^{* * *}(0,0000)$ & $-53,5409^{* * *}(0,0001)$ \\
\hline CRFSA & $0,149^{* * *}(0,0000)$ & $-37,9548^{* * *}(0,0000)$ \\
\hline$D O A S$ & $0,094^{* * *}(0,0000)$ & $-49,2426^{* * *}(0,0001)$ \\
\hline$D O C O$ & $0,088^{* * *}(0,0000)$ & $-35,5409^{* * *}(0,0000)$ \\
\hline KIPA & $0,153^{* * *}(0,0000)$ & $-54,6840^{* * *}(0,0001)$ \\
\hline MGROS & $0,081^{* * *}(0,0000)$ & $-55,2974^{* * *}(0,0001)$ \\
\hline NTTUR & $0,164^{* * *}(0,0000)$ & $-55,9683^{* * *}(0,0001)$ \\
\hline$O D A S$ & $0,100^{* * *}(0,0000)$ & $-23,4815^{* * *}(0,0000)$ \\
\hline PGSUS & $0,057^{* * *}(0,0000)$ & $-24,3714^{* * *}(0,0000)$ \\
\hline TATGD & $0,075^{* * *}(0,0000)$ & $-55,2782^{* * *}(0,0001)$ \\
\hline TCELL & $0,073^{* * * *}(0,0000)$ & $-56,6422^{* * *}(0,0001)$ \\
\hline THYАO & $0,065^{* * *}(0,0000)$ & $-54,4675^{* * *}(0,0001)$ \\
\hline TKNSA & $0,096^{* * *}(0,0000)$ & $-28,3207^{* * *}(0,0000)$ \\
\hline TTKOM & $0,096^{* * *}(0,0000)$ & $-42,6552^{* * *}(0,0000)$ \\
\hline ULKER & $0,083^{* * *}(0,0000)$ & $-54,3691^{* * *}(0,0001)$ \\
\hline ZOREN & $0,136^{* * *}(0,0000)$ & $-41,8240^{* * *}(0,0000)$ \\
\hline
\end{tabular}

Tablo 5, analize dahil edilen yirmi iki payda hicri takvim etkisinin varlığını ortaya koymak için kullanılan kukla değişkenli regresyon modeli (Denklem 2) ve Kruskal-Wallis testi (Denklem 3) sonuçlarını göstermektedir. Hicri takvimin aylarına ilişskin kukla değişkenlerin katsayıları tek tek incelenirse, Cemaziyülahır, Şaban ve Zilkade aylarında, hiçbir paya ait katsayının istatistiksel olarak anlamlı olmadığı görülmektedir. Hicri yılın diğer aylarında ise, kukla değişkenlere ait katsayıların istatistiksel olarak anlamlı bir şekilde bazı aylarda pozitif, bazı aylarda ise negatif olduğu göze çarpmaktadır. Bir başka ifadeyle belirtilen aylarda paylar, yatırımcılarına pozitif veya negatif getiri sağlamaktadır. Örneğin Safer (TKNSA), Muharrem (THYAO), Rebiyülahir (CRFSA ve KIPA) ve Recep (CRFSA ve KIPA) aylarında parantez içinde belirtilen paylar istatistiksel olarak anlamlı pozitif getiri sağlarken; Safer (CLEBI ve THYAO), Rebiyülevvel (AKENR, PGSUS ve ULKER), Cemaziyülevvel (AKENR, CLEBI, DOAS ve THYAO), Recep (AKSEN), Şevval (CLEBI, ODAS, TTKOM VE ULKER) ve Zilhicce (AKSEN) aylarında parantez içinde belirtilen payların istatistiksel olarak anlamlı negatif getiriler sağladığı görülmektedir.

Tablo 5'te Ramazan ayına ilişkin analiz sonuçları incelendiğinde, istatistiksel olarak anlamlı bir şekilde TKNSA payının pozitif getiriye $\left(\beta_{9 \text { TKNSA }}=0,005130\right.$; t-istatistiği $\left.=2,1785\right)$; MGROS ve ULKER paylarının ise negatif getiriye sahip olduğu görülmektedir ( $\beta_{9 \text { MGROS }}=-0,003136$, t-istatistiği $=-1,6470 ; \beta_{9 U L K E R}=-0,004012$, t-istatistiğ $\left.\mathrm{i}=-1,7530\right)$. Bir başka ifadeyle literatürde yer alan bulguların aksine, Ramazan ayında TKNSA dışındaki diğer payların istatistiksel olarak anlamlı pozitif ve hicri yılın diğer aylara göre yüksek getiriler sağlamadığı söylenebilir. Kukla değişkenli regresyon modelinde, tüm eğim katsayılarının sıfırdan farklı olup olmadığını gösteren $\mathrm{F}$ istatistiği sonuçlarına göre ise, \%10 istatistiksel anlamlılık düzeylerinde AKENR, CLEBI ve CRFSA paylarının; \%5 istatistiksel anlamlılık düzeylerinde ise, KIPA payının eğim katsayılarının sıfıra eşit olmadığı görülmektedir. 
Özkan, N., Akbalık, M. / Journal of Yasar University, 2018, 13/49, 9-21

Tablo 5. Ramazan Ayı Etkisine İlişkin Analiz Sonuçlar

\begin{tabular}{|c|c|c|c|c|c|c|c|c|c|c|c|}
\hline & AEFES & AKENR & AKSEN & BIMAS & BIZIM & CCOLA & CLEBI & CRFSA & DOAS & DOCO & KIPA \\
\hline \multirow[t]{2}{*}{ Sabit (Muharrem) } & 0,000409 & 0,001094 & 0,002195 & 0,001944 & $-0,000003$ & 0,000181 & 0,002852 & 0,000099 & 0,002148 & 0,002631 & $-0,000736$ \\
\hline & $(0,3150)$ & $(0,6652)$ & $(1,1754)$ & $(1,6436)$ & $(-0,0013)$ & $(0,1113)$ & $(1,4841)$ & $(0,0554)$ & $(1,0194)$ & $(1,5434)$ & $(-0,4076)$ \\
\hline \multirow[t]{2}{*}{ Safer } & $-0,000579$ & $-0,000191$ & $-0,000609$ & $-0,001261$ & 0,002766 & $-0,000600$ & $-0,004438^{*}$ & $-0,001740$ & $-0,004819$ & $-0,000900$ & 0,000363 \\
\hline & $(-0,3193)$ & $(-0,0910)$ & $(-0,2045)$ & $(-0,7307)$ & $(0,9532)$ & $(-0,2494)$ & $(-1,7462)$ & $(-0,8109)$ & $(-1,6094)$ & $(-0,3994)$ & $(0,1561)$ \\
\hline \multirow[t]{2}{*}{ Rebiyülevvel } & $-0,000389$ & $-0,003748^{*}$ & $-0,002893$ & $-0,001572$ & $-0,001799$ & $-0,000652$ & $-0,003220$ & 0,002387 & 0,000425 & $-0,000834$ & 0,000828 \\
\hline & $(-0,2324)$ & $(-1,7467)$ & $(-1,1166)$ & $(-0,8546)$ & $(-0,6562)$ & $(-0,2796)$ & $(-1,2912)$ & $(0,8649)$ & $(0,1497)$ & $(-0,3781)$ & $(0,3928)$ \\
\hline \multirow[t]{2}{*}{ Rebiyülahir } & $-0,000848$ & 0,000969 & $-0,000484$ & 0,000995 & 0,001458 & $-0,000358$ & 0,000157 & $0,006082^{*}$ & $-0,000761$ & $-0,001422$ & $0,004984^{* *}$ \\
\hline & $(-0,4769)$ & $(0,4436)$ & $(-0,2064)$ & $(0,5317)$ & $(0,5297)$ & $(-0,1635)$ & $(0,0600)$ & $(1,9288)$ & $(-0,2297)$ & $(-0,6460)$ & $(2,1165)$ \\
\hline \multirow[t]{2}{*}{ Cemaziyülevvel } & 0,002493 & $-0,003847^{*}$ & $-0,002408$ & $-0,001341$ & 0,000176 & 0,001750 & $-0,004529^{*}$ & 0,000063 & $-0,005144^{*}$ & $-0,000720$ & 0,002482 \\
\hline & $(1,4494)$ & $(-1,7789)$ & $(-0,9387)$ & $(-0,6951)$ & $(0,0642)$ & $(0,7851)$ & $(-1,9484)$ & $(0,0255)$ & $(-1,9254)$ & $(-0,3030)$ & $(1,0714)$ \\
\hline \multirow[t]{2}{*}{ Cemaziyülahır } & $-0,000275$ & 0,001927 & $-0,002424$ & $-0,000299$ & $-0,000802$ & 0,000470 & $-0,003987$ & $-0,000833$ & $-0,001406$ & $-0,002835$ & $-0,000464$ \\
\hline & $(-0,1525)$ & $(0,8740)$ & $(-1,0529)$ & $(-0,1751)$ & $(-0,2888)$ & $(0,2012)$ & $(-1,4921)$ & $(-0,2581)$ & $(-0,4849)$ & $(-1,3256)$ & $(-0,2093)$ \\
\hline \multirow[t]{2}{*}{ Recep } & 0,002643 & $-0,000542$ & $-0,005530^{*}$ & 0,000621 & $-0,000999$ & 0,002284 & $-0,001512$ & $0,004585^{*}$ & 0,001931 & $-0,000196$ & $0,004127^{*}$ \\
\hline & $(1,3778)$ & $(-0,2497)$ & $(-1,8980)$ & $(0,3159)$ & $(-0,3613)$ & $(1,0535)$ & $(-0,5986)$ & $(1,6697)$ & $(0,6763)$ & $(-0,0842)$ & $(1,7585)$ \\
\hline \multirow[t]{2}{*}{ Şaban } & 0,000164 & $-0,001925$ & $-0,004093$ & 0,000140 & $-0,002211$ & 0,000380 & 0,000706 & $-0,001755$ & $-0,002742$ & $-0,001601$ & 0,002390 \\
\hline & $(0,0856)$ & $(-0,9302)$ & $(-1,4560)$ & $(0,0894)$ & $(-0,8034)$ & $(0,1657)$ & $(0,2529)$ & $(-0,8058)$ & $(-1,0993)$ & $(-0,6763)$ & $(0,9814)$ \\
\hline \multirow[t]{2}{*}{ Ramazan } & 0,000032 & 0,000422 & $-0,003432$ & $-0,002188$ & $-0,002547$ & $-0,000004$ & $-0,001792$ & $-0,002220$ & 0,000150 & $-0,001757$ & $-0,000340$ \\
\hline & $(0,0165)$ & $(0,1923)$ & $(-1,1846)$ & $(-1,1706)$ & $(-0,9275)$ & $(-0,0016)$ & $(-0,7094)$ & $(-0,9275)$ & $(0,0547)$ & $(-0,5966)$ & $(-0,1571)$ \\
\hline \multirow[t]{2}{*}{ Şevval } & 0,000696 & $-0,001948$ & $-0,003716$ & $-0,002673$ & $-0,002249$ & $-0,002171$ & $-0,006843^{* *}$ & 0,000119 & $-0,004838$ & $-0,001604$ & $-0,001881$ \\
\hline & $(0,3442)$ & $(-0,8245)$ & $(-1,3432)$ & $(-1,3808)$ & $(-0,7965)$ & $(-0,7835)$ & $(-2,1311)$ & $(0,0478)$ & $(-1,4294)$ & $(0,6840)$ & $(-0,7704)$ \\
\hline \multirow[t]{2}{*}{ Zilkade } & $-0,000795$ & $-0,001225$ & $-0,000150$ & $-0,000489$ & 0,001546 & 0,002233 & 0,000514 & $-0,000392$ & $-0,003035$ & $-0,002942$ & $-0,000847$ \\
\hline & $(-0,4697)$ & $(-0,4581)$ & $(-0,0564)$ & $(-0,2079)$ & $(0,5630)$ & $(0,8882)$ & $(0,1831)$ & $(-0,1867)$ & $(-1,0221)$ & $(-1,5035)$ & $(-0,3631)$ \\
\hline \multirow[t]{2}{*}{ Zilhicce } & 0,000353 & $-0,002666$ & $-0,004603^{*}$ & $-0,000103$ & $-0,000578$ & 0,001923 & $-0,000346$ & $-0,000576$ & $-0,000667$ & 0,000854 & 0,000765 \\
\hline & $(0,1777)$ & $(-1,1455)$ & $(-1,8187)$ & $(-0,0562)$ & $(-0,2035)$ & $(0,8128)$ & $(-0,1294)$ & $(-0,2594)$ & $(-0,2475)$ & $(0,2553)$ & $(0,3644)$ \\
\hline $\mathrm{R}^{2}$ & 0,0022 & 0,0049 & 0,0075 & 0,0020 & 0,0074 & 0,0029 & 0,0065 & 0,0125 & 0,0065 & 0,0037 & 0,0070 \\
\hline DW & 2,0705 & 1,9139 & 2,0448 & 2,0997 & 1,8903 & 2,0632 & 1,9124 & 2,0180 & 1,8469 & 1,9446 & 1,9548 \\
\hline F-İstatistiği & 0,8619 & $1,578^{*}$ & 0,951 & 0,638 & 0,794 & 0,588 & $1,614^{*}$ & $1,581^{*}$ & 1,465 & 0,533 & 1,8922 \\
\hline (p-değeri) & $(0,578)$ & $(0,098)$ & $(0,489)$ & $(0,797)$ & $(0,646)$ & $(0,840)$ & $(\mathbf{0 , 0 8 8 )}$ & $(0,098)$ & $(0,137)$ & $(0,881)$ & $(0,036)$ \\
\hline KW & 11,565 & $17,786^{*}$ & 9,616 & 5,730 & 5,804 & 8,872 & 12,874 & 8,859 & 15,504 & 4,033 & $25,122^{* * *}$ \\
\hline (p-değeri) & $(0,397)$ & $(0,087)$ & $(0,565)$ & $(0,891)$ & $(0,886)$ & $(0,634)$ & $(0,302)$ & $(0,635)$ & $(0,161)$ & $(0,969)$ & $(0,009)$ \\
\hline
\end{tabular}


Tablo 5 (devam ediyor)

\begin{tabular}{|c|c|c|c|c|c|c|c|c|c|c|c|}
\hline & MGROS & NTTUR & ODAS & PGSUS & TATGD & TCELL & THYAO & TKNSA & TTKOM & ULKER & ZOREN \\
\hline \multirow[t]{2}{*}{ Sabit (Muharrem) } & 0,001661 & $-0,000190$ & 0,000596 & 0,004305 & $-0,000196$ & 0,001030 & $0,002393^{*}$ & $-0,001763$ & 0,001454 & 0,003196 & 0,001044 \\
\hline & $(1,1226)$ & $(-0,1185)$ & $(0,1705)$ & $(1,0264)$ & $(-0,1308)$ & $(0,7335)$ & $(1,6970)$ & $(-1,0889)$ & $(0,8267)$ & $(1,6438)$ & $(0,5789)$ \\
\hline \multirow[t]{2}{*}{ Safer } & $-0,001816$ & 0,003698 & $-0,000836$ & $-0,003581$ & 0,000180 & $-0,001528$ & $-0,003986^{*}$ & $0,004856^{\text {*** }}$ & $-0,000434$ & $-0,003659$ & $-0,002740$ \\
\hline & $(-0,8976)$ & $(1,2577)$ & $(-0,1359)$ & $(-0,5701)$ & $(0,0826)$ & $(-0,7723)$ & $(-1,8902)$ & $(2,0887)$ & $(-0,1752)$ & $(-1,4670)$ & $(-1,1495)$ \\
\hline \multirow[t]{2}{*}{ Rebiyülevvel } & $-0,001467$ & $-0,000002$ & 0,003417 & $-0,013818^{* *}$ & $-0,000453$ & $-0,002401$ & $-0,001589$ & 0,002283 & $-0,001250$ & $-0,004733^{*}$ & $-0,001137$ \\
\hline & $(-0,7552)$ & $(-0,0007)$ & $(0,6863)$ & $(-2,1897)$ & $(-0,2311)$ & $(-1,2104)$ & $(-0,7395)$ & $(0,8085)$ & $(-0,5069)$ & $(-1,9419)$ & $(-0,4713)$ \\
\hline \multirow[t]{2}{*}{ Rebiyülahir } & 0,001299 & 0,002286 & 0,006207 & $-0,004267$ & 0,002228 & $-0,001348$ & $-0,001465$ & 0,000092 & 0,000276 & $-0,002073$ & 0,000871 \\
\hline & $(0,5895)$ & $(0,9265)$ & $(0,9977)$ & $(-0,7040)$ & $(1,0672)$ & $(-0,6790)$ & $(-0,7279)$ & $(0,0341)$ & $(0,1113)$ & $(-0,8795)$ & $(0,3428)$ \\
\hline \multirow[t]{2}{*}{ Cemaziyülevvel } & $-0,002255$ & $-0,001187$ & 0,002021 & $-0,008106$ & $-0,000028$ & $-0,001376$ & $-0,003930^{* *}$ & 0,002437 & $-0,000822$ & $-0,002008$ & $-0,000404$ \\
\hline & $(-1,0477)$ & $(-0,4749)$ & $(0,2416)$ & $(-1,4231)$ & $(-0,0138)$ & $(-0,6932)$ & $(-2,1359)$ & $(0,7376)$ & $(-0,3386)$ & $(-0,7799)$ & $(-0,1801)$ \\
\hline \multirow[t]{2}{*}{ Cemaziyülahır } & $-0,001137$ & $-0,000174$ & 0,003715 & $-0,004545$ & 0,003236 & $-0,002819$ & $-0,002329$ & 0,002166 & $-0,003152$ & $-0,000728$ & $-0,000718$ \\
\hline & $(-0,5701)$ & $(-0,0783)$ & $(0,6620)$ & $(-0,8868)$ & $(1,6240)$ & $(-1,4172)$ & $(-1,1228)$ & $(0,7930)$ & $(-1,3035)$ & $(-0,2942)$ & $(-0,2819)$ \\
\hline \multirow[t]{2}{*}{ Recep } & 0,001045 & 0,000927 & $-0,002049$ & 0,00002 & 0,001724 & 0,000672 & 0,000191 & 0,003036 & 0,001092 & 0,000007 & $-0,000495$ \\
\hline & $(0,5038)$ & $(0,4345)$ & $(-0,3120)$ & $(0,0033)$ & $(0,8951)$ & $(0,3385)$ & $(0,0946)$ & $(0,8975)$ & $(0,4536)$ & $(0,0026)$ & $(-0,2031)$ \\
\hline \multirow[t]{2}{*}{ Şaban } & 0,001172 & 0,000006 & $-0,003538$ & $-0,004106$ & 0,001081 & 0,001660 & $-0,000207$ & $-0,000232$ & $-0,003026$ & $-0,001295$ & $-0,001731$ \\
\hline & $(0,4900)$ & $(0,0025)$ & $(-0,7997)$ & $(-0,7941)$ & $(0,4953)$ & $(0,8369)$ & $(-0,1059)$ & $(-0,0880)$ & $(-1,2586)$ & $(-0,5383)$ & $(-0,7423)$ \\
\hline \multirow[t]{2}{*}{ Ramazan } & $-0,003136 *$ & 0,000897 & $-0,000268$ & $-0,001307$ & $-0,001162$ & 0,001072 & $-0,000806$ & $0,005130^{* *}$ & 0,000375 & $-0,004012^{*}$ & $-0,000839$ \\
\hline & $(-1,6470)$ & $(0,3538)$ & $(-0,0650)$ & $(-0,2587)$ & $(-0,5352)$ & $(0,5388)$ & $(-0,3687)$ & $(\mathbf{2 , 1 7 8 5 )}$ & $(0,1562)$ & $(-1,7530)$ & $(-0,3096)$ \\
\hline \multirow[t]{2}{*}{ Şevval } & $-0,002470$ & 0,001957 & $-0,008036^{*}$ & $-0,009442$ & 0,000766 & 0,000599 & $-0,004279$ & $-0,005185$ & $-0,005457^{* * *}$ & $-0,005186^{* *}$ & $-0,003592$ \\
\hline & $(-1,0892)$ & $(0,7920)$ & $(-1,7940)$ & $(-1,6382)$ & $(0,3258)$ & $(0,2937)$ & $(-1,4896)$ & $(-1,5947)$ & $(-2,2122)$ & $(-2,0570)$ & $(-1,1805)$ \\
\hline \multirow[t]{2}{*}{ Zilkade } & $-0,001805$ & 0,001377 & 0,000240 & $-0,003210$ & 0,002049 & 0,000205 & 0,000391 & 0,000696 & $-0,001990$ & $-0,001834$ & $-0,000039$ \\
\hline & $(-0,9087)$ & $(0,6155)$ & $(0,0520)$ & $(-0,6154)$ & $(0,9981)$ & $(0,1035)$ & $(0,1816)$ & $(0,2921)$ & $(-0,8289)$ & $(-0,7351)$ & $(-0,0165)$ \\
\hline \multirow[t]{2}{*}{ Zilhicce } & $-0,002612$ & 0,001248 & 0,003881 & $-0,000828$ & $-0,000832$ & $-0,000561$ & $-0,001716$ & 0,004006 & $-0,000584$ & $-0,000126$ & $-0,001216$ \\
\hline & $(-1,2935)$ & $(0,5582)$ & $(0,8890)$ & $(-0,1667)$ & $(-0,4287)$ & $(-0,2724)$ & $(-0,8312)$ & $(1,2878)$ & $(-0,2345)$ & $(-0,0519)$ & $(-0,4045)$ \\
\hline $\mathrm{R}^{2}$ & 0,0040 & 0,0019 & 0,0177 & 0,0213 & 0,0030 & 0,0035 & 0,0042 & 0,0167 & 0,0072 & 0,0047 & 0,0017 \\
\hline DW & 1,9700 & 1,9910 & 1,9571 & 1,9907 & 1,9681 & 2,0213 & 1,9400 & 1,9662 & 1,9916 & 1,9384 & 1,9320 \\
\hline F-İstatistiği & 1,096 & 0,433 & 1,400 & 1,048 & 0,985 & 1,009 & 1,172 & 1,509 & 1,211 & 1,4140 & 0,413 \\
\hline (p-değeri) & $(0,360)$ & $(0,942)$ & $(0,168)$ & $(0,402)$ & $(0,457)$ & $(0,435)$ & $(0,301)$ & $(0,123)$ & $(0,274)$ & $(0,159)$ & $(0,951)$ \\
\hline KW & 10,207 & 4,684 & 13,163 & 11,993 & 11,620 & 6,888 & 12,571 & $18,271^{*}$ & 16,630 & 13,323 & 5,880 \\
\hline (p-değeri) & $(0,512)$ & $(0,946)$ & $(0,283)$ & $(0,364)$ & $(0,393)$ & $(0,808)$ & $(0,322)$ & $(0,076)$ & $(0,119)$ & $(0,273)$ & $(0,881)$ \\
\hline \multirow{2}{*}{\multicolumn{12}{|c|}{$\begin{array}{l}\text { Borsa İstanbul'da gıda-içecek, hizmetler ve ulaştırma endekslerinde işlem gören piyasa değeri yüksek } 22 \text { pay için Ramazan ayı etkisini belirlemek için kullanılan kukla değişkenli regresyon modeline (Denklem } \\
\text { 2) ilişkin sonuçlar tabloda sunulmaktadır. BIZIM, TCELL ve TTKOM dişındaki paylara ilişkin regresyon modelleri White'ın değişen varyans ya da Newey-West'in değişen varyans ve otokorelasyona tutarlı } \\
\text { kovaryans matrisleri kullanılarak en kücük kareler yöntemi ile tahmin edilmistir. Parantez içindeki değerler katsaviların t-istatistikleridir. }\end{array}$}} \\
\hline & & & & & & & & & & & \\
\hline \multicolumn{12}{|c|}{ F istatistiği sonuçlarına göre, p-değerinin \%10'dan küçük (büyük) olması, regresyonda yer alan tüm eğim katsayılarının sıfıra eşit olmadığı (olduğu) anlamına gelmektedir. } \\
\hline \multicolumn{12}{|c|}{$\begin{array}{l}\text { Kruskal Wallis testi }(\mathrm{KW}) \text { sonuçlarına göre, p-değerinin \%10'dan küçük (büyük) olması, payların hicri aylarda sağladığı ortalama getiriler arasında farklılık olduğu (olmadığı) anlamına gelmektedir. } \\
*_{* * *}^{* *},{ }^{*} \text { sirasıyla } \% 1, \% 5 \text { ve \%10 düzeyinde anlamlılığı göstermektedir. }\end{array}$} \\
\hline
\end{tabular}


Kukla değişkenli regresyon modelinin bulgularının doğruluğunu teyit etmek için gerçekleştirilen Kruskal-Wallis testi sonuçları, AKENR, KIPA ve TKNSA dışındaki tüm paylar için istatistiksel olarak anlamsızdır. Bu nedenle bu üç payın hicri aylarda sağladığı ortalama getiriler arasında farklılık olmadığını ileri süren $\mathrm{H}_{0}$ hipotezi reddedilmekte ve hicri aylarda farklı ortalama getiriler sağladıkları ortaya koyulmaktadır. Bu bağlamda, AKENR payı üzerinde Rebiyülevvel ve Cemaziyülevvel aylarının negatif; KIPA payı üzerinde ise, Rebiyülahir ve Recep aylarının pozitif etkisinin olduğu söylenebilir. Kruskal-Wallis testi sonuçlarına göre, Ramazan ayı etkisinin ise, sadece TKNSA payında olduğu görülmektedir. Ancak, TKNSA payına iliş̧kin bu bulgular, F istatistiği sonuçlarıyla uyuşmamaktadır. Bu nedenle çalışmada, Akbalık (2015) tarafından XUHIZ ve XULAS endekslerinde ortaya koyulan Ramazan ayı etkisinin varlı̆ı̆ını destekleyen güçlü bulgular sunulamamaktadır. Diğer taraftan, Akbalık (2015)'in sonuçlarıyla uyumlu bir şekilde XGIDA endeksinde yer alan paylar için Ramazan ayı etkisinin olmadığı bulunmuştur.

\section{Sonuç}

Son yıllarda Müslüman ülkelerde, payların hicri takvimin aylarına göre faklı ortalama getiriler sağlayıp sağlamadığı birçok araştırmaya konu olmuştur. Bu konuyla ilgili literatür incelendiğinde, payların en yüksek ortalama getiri ve en düşük oynaklı̆̆a Ramazan ayında sahip oldukları ileri sürülmektedir. Bu durum, literatürde Ramazan ayı etkisi (the Ramadan effect) olarak bilinmektedir. Bu çalışmada Borsa İstanbul pay piyasasında, BIST Gıda ve İçecek (XGIDA), BIST Hizmetler (XUHIZ) ve BIST Ulaştırma (XULAS) endekslerinde yer alan 22 payın 4 Mart 2003 - 13 Ekim 2015 (1 Muharrem 1424 - 29 Zilhicce 1436) tarihleri arasındaki verileri kullanılarak hicri takvim etkisinin varlığı araştırılmaktadır. Çalışmada hicri takvim etkisinin varlığını belirlemek içinse, kukla değişkenli regresyon modeli ve Kruskal-Wallis testinden yararlanılmaktadır.

Çalışmada elde edilen bulgular, XUHIZ endeksinde yer alan AKENR ve KIPA payları dışında diğer tüm payların hicri aylarda sağladığı ortalama getiriler arasında farklılık olmadığını göstermektedir. Bu sonuca göre, AKENR payı Rebiyülevvel ve Cemaziyülevvel aylarından negatif; KIPA payı Rebiyülahir ve Recep aylarından pozitif olarak etkilenmektedir. Bu bulgular, son yıllarda hicri takvim ve özellikle de Ramazan ayı etkisinin hemen hemen tüm paylar için ortadan kaybolduğu anlamına gelmektedir. Bu sonuç, Akbalık (2015)'in XGIDA endeksinde Ramazan ayı etkisinin olmadığını ileri süren bulguları ile uyumlu iken; XUHIZ ve XULAS endekslerinde Ramazan ayı etkisinin varlığını ileri süren bulguları ile çelişmektedir. $\mathrm{Bu}$ durumun çalışmada kullanılan farklı veri seti (endeks yerine bireysel paylar), zaman aralığ metodolojilerden kaynaklanabileceği düşünülmektedir. Ayrıca bu durum, Borsa İstanbul'un son yıllarda küresel finans piyasaları ile entegrasyonunun artarak daha etkin hale gelmesi ve bununla birlikte piyasada mevsimsel etkileri kullanarak aşırı getiri elde etmenin zorlaşması gibi nedenlerle de açıklanabilir.

Bundan sonra yapılacak çalışmalarda elde edilen bu bulguların geçerliliği, farklı metodolojiler kullanılarak karşılaştırılabilir. Ayrıca incelenen veri seti genişletilebilir ve dönem 2008 küresel ekonomik krizi dikkate alınarak alt dönemlere bölünüp krizin hicri takvim anomalisi üzerindeki etkisi incelenebilir. 
Özkan, N., Akbalık, M. / Journal of Yasar University, 2018, 13/49, 9-21

\section{KAYNAKÇA}

Akbalık, Murat. 2015. "An Analysis of the Effect of Ramadan on Istanbul Stock Exchange". R. Yılmaz, G. Löschnigg, H. Arslan ve M. A. Icbay (Eds.), Current Approaches in Social Sciences (573-579). Peter Lang: Peter Lang GmbH.

Al-Hajieh, Heitham, Keith Redhead ve Timothy Rodgers. 2011. "Investor Sentiment and Calendar Anomaly Effects: A Case Study of the Impact of Ramadan on Islamic Middle Eastern Markets". Research in International Business and Finance 25(3): 345-356.

Al-Khazali, Osamah. 2014. "Revisiting Fast Profit Investor Sentiment and Stock Returns During Ramadan". International Review of Financial Analysis 33: 158-170.

Almudhaf, Fahad. 2012. "The Islamic Calendar Effects: Evidence from Twelve Stock Markets". International Research Journal of Finance and Economics (87): 185-191.

Alrashidi, Faleh, Manzoor Ahmed ve Fahad Beneid. 2014. "The Calendar Impact and Trading Behavior: An Empirical Evidence from around the Globe". The International Business \& Economics Research Journal 13(5): 1025-1032.

Ariss, Rima Turk, Rasoul Rezvanian ve Seyed M. Mehdian. 2011. "Calendar Anomalies in the Gulf Cooperation Council Stock Markets". Emerging Markets Review, 12(3): 293-307.

Białkowski, Jędrzej, Martin T. Bohl, Philipp Kaufmann ve Tomasz P. Wisniewski. 2013. "Do Mutual Fund Managers Exploit the Ramadan Anomaly? Evidence from Turkey". Emerging Markets Review, 15: 211-232.

Białkowski, Jędrzej, Ahmad Etebari ve Tomasz Piotr Wisniewski. 2012. "Fast Profits: Investor Sentiment and Stock Returns During Ramadan". Journal of Banking \& Finance 36(3): 835-845.

Erdoğan, Muammer ve Bekir Elmas. 2010. "Hisse Senedi Piyasalarında Görülen Anomaliler ve Bireysel Yatırımcı Üzerine Bir Araştırma". Atatürk Üniversitesi Sosyal Bilimler Enstitüsü Dergisi 14(2): 1-22.

Ergül, Nuray, Veli Akel ve Sezai Dumanoğlu. 2009. "Sektör Endekslerinde Haftanını Günü Etkisinin Araştıılması". Muhasebe Bilim Dünyası Dergisi 11(2): 129-152.

Ergül, Nuray, Sezai Dumanoğlu ve Veli Akel. 2008. "İMKB'de Günlük Anomaliler". Marmara Üniversitesi İ.İ.B.F. Dergisi 25(2): 601-629.

Hui, Tak-Kee. 2005. "Day-of-the-Week Effects in US and Asia-Pacific Stock Markets During the Asian Financial Crisis: A Non-Parametric Approach". Omega 33(3): 277-282.

Husain, Fazal. 1998. "A Seasonality in the Pakistani Equity Market: The Ramadhan Effect". The Pakistan Development Review 37(1): 77-81.

Iqbal, Muhammad Shahid, Rehana Kouser ve Muhammad Azeem. 2013. "Conventional and Islamic Anomalies in Karachi Stock Exchange". Science International 25(4): 999-1007.

Kalayc1, Şeref. 2010. SPSS Uygulamalı Çok Değişkenli İstatistik Teknikleri (5. Baskı). Ankara: Asil Yayın Dağıtım.

Kumar, Satish ve Rajesh Pathak. 2016. "Do the Calendar Anomalies Still Exist? Evidence from Indian Currency Market". Managerial Finance 42(2): 136-150.

Küçüksille, Engin ve Nezih Metin Özmutaf. 2015. "Is There Ramadan Effect in Turkish Stock Market?". Uluslararası Alanya İsletme Fakültesi Dergisi 7(3): 137-142.

Lim, Shiok Ye ve Ricky Chee-Jiun Chia. 2010. "Stock Market Calendar Anomalies: Evidence from Asean - 5 Stock Markets". Economics Bulletin, 30(2): 996-1005.

Mustafa, Khalid. 2011. "The Islamic Calendar Effect on Karachi Stock Market". Pakistani Business Review 562-574.

Oğuzsoy, Cemal Berk ve Sibel Güven. 2004. "Holy Days Effect on Istanbul Stock Exchange". Journal of Emerging Market Finance 3(1): 63-75.

Seyyed, Fazal J., Abraham Abraham ve Mohsen Al-Hajji. 2005. "Seasonality in Stock Returns and Volatility: The Ramadan Effect". Research in International Business and Finance 19(3): 374-383.

Tunçel, Ahmet Kamil. 2007. "IMKB'de Haftanın Günü Etkisi". Akdeniz Üniversitesi IIÍBF Dergisi 13: 252-265.

Unat, Yavuz. 2004. "İslâm'da Ve Türklerde Zaman ve Takvim". Ö. Oğuz (Ed.), Türk Dünyası, Nevruz Ansiklopedisi (15-24). Ankara: Atatürk Kültür Merkezi Başkanlığı Yayınları. 